\title{
ETHICS IN CHILD PROGRAM IMPRESSIONS ON TELEVISION
}

\section{El Chris Natalia, S.I.Kom.,}

\section{M.Si.}

Universitas Katolik Indonesia Atma Jaya

Email : chris.natalia@atmajaya.ac.id

Although nowadays the new media comes to exist in the society, the conventional media like television is still be a part of Indonesian society, especially in the areas that is untouched by the internet. Television still has its own audience. Television is obliged to perform its functions in providing information, educate, entertain, control and also as a social adhesive. Children as one of television audiences always get more attention because children are the next generation who are very easily influenced by this audiovisual media. Children are the easiest figure to imitate what they see on television. Ethics in children's program broadcasted in television is important to avoid the damage of children development in both psychologically and physically.

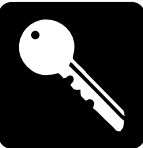

Ethics, television, children 


\section{INTRODUCTION}

$\mathrm{M}$ ass media plays a role in our daily lives. Imagine what would happen if there was no mass media. Mass media really help us in providing various information. According Bungin (2006), mass media is mass communication and information media and can be accessed by society en masse also. Mass media has a function as a medium to provide information, educate, entertain, and influence. What is broadcast or published in the mass media can have an impact on social changes.

The social changes caused by the media that often occur among children is the act of impersonation by children, which will be a new trend for them and it will bring an impact that could be detrimental. Vulnerability of children in consuming the media to make a lot of people, especially parents are very concerned about children's development. As audiovisual media, television has always been the medium that many people talk about. Many people often talk about the right children to broadcast on television. Through the audiovisual medium, children are interested in watching or consuming broadcasted impressions. Children can learn more than just the facts aired by television.

Nowadays, children's TV programs are getting smaller and more distant from the word "educate". Impressions of children's programs on television only emphasize ratings and pursue advertising regardless of content. The television media just prioritize the economic side compared to education. Television programs in Indonesia more often contain content about violence, mystic or horror, pornography, or other non-educational matters. Impressions of children's programs on television are diminishing, even if there are impressions for children, they are violent and non-educational.

There are many examples of children's television programs that are not educative for the children themselves. As an example of children who are dangerous and not educational according to the Indonesian Broadcasting Commission (KPI) is a child show Little Krishna and Tom \& Jerry. Both of these impressions are judged to be full of contents that have an adverse effect on the child's physical and mental development, including the presence of violence and negative traits (such as emotional, stingy, ignorant, greedy, etc.). Both of these examples seem to prove that there is still indifference of the television media as a broadcaster in broadcasting children's impressions.

Children should be a concern in the world of mass media. They should be able to get a special position in television shows. Children are considered an easily influenced figure, especially through television media that accentuate the audiovisual aspect. What television shows can get into the imagination of children and they can learn or imitate from the show. Because children have the ability to mimic what they are watching, this is where the ethical role of the programs is played.

When talking about ethics in the media, we will also be talking about the rules in the media as well as the values prevailing in society. Television has always claimed its responsibility as a medium in promoting positive and educational values. Various regulations in broadcasting impressions on television have been arranged in such a way as in Law No. 32 of 2002 and 
Broadcasting Behavior and Broadcast Program Standards (P3SPS) of 2012 prepared by the Indonesian Broadcasting Commission (KPI). These rules are set up as guidelines or guidelines and restrictions for broadcasting media agencies in broadcasting their programs. In this case, the television media is also closely related to the regulation. The values or norms prevailing in society are also an important part of the mass media. What is allowed and should not be or what is inappropriate and inappropriate in society (in this case is the society in Indonesia) must be considered by the television media in broadcasting the program. Ethics in broadcasters plays an important role and is closely related to children as their segmentation.

The issue of ethics in broadcasting television programs or programs is never ending to be discussed. Questions arise when we talk about the ability of the television media to persuade children who give rise. Is the scene of violence in child program impressions appropriate for children to consume? How should the media package children's entertaining but educational impressions? What kind of impressions should children take? When we discuss about program impressions for children, we will also discuss ethics and morals in the show.

\section{LITERATURE REVIEW II.I. Media Television}

Maybe we often hear that television is the window of the world. Television gives various images of what is and what is happening in the world. People do not need to go outdoors to see one by one whatever is going on around. Television is able to present it to the public. Burton (2007: 7) gives a sense of television, an experience that we take for granted. Nevertheless, television is also something that shapes our way of thinking about the world. "One reason why television is often considered to be so ideologically charged is that it relies, almost exclusively, on conventional, 'realist' forms of image construction that mask the workings of the camera" (Croteau et al., 2012: 171). Television describes the reality that happens in our daily lives. Reality is created and packaged by the television media-writers, producers, and others-in order to attract the attention of audiences. In addition to describing something through the medium of television, television is also used by some parties as a tool in promoting or advertising something. Television also provides many illustrations and information through its programs.

Broadcasting Act No.32 of 2002 Article 4 asserts that broadcasting as a mass communication activity serves as a medium of information, education, healthy entertainment, control, and social adhesives. In addition, broadcasting also has economic and cultural functions. Based on the Act, basically television as broadcast media also has the same function. Ardianto et al. (2009) explained that the function of television together with other mass media, which is to provide information, educate, entertain and persuade. Television characteristics are audiovisual, think in pictures, and more complex operations. Messages to be delivered via the television media, require other considerations for the message can be accepted by the target audience. Factors to note are the audience, time, duration, and method of presentation.

Based on the presentation of Ardianto et al. (2009), the characteristics of television 
as audiovisual explains that there must be a harmony between the image and the words presented. While on the characteristics of thinking in the picture, there are two stages performed, namely visualization and depiction. Television helps its audiences in translating words that contain ideas that are visual images and also in assembling individual images so that their continuity contains certain meanings.

What is presented by television contains a meaning in which the audience who watch it can perceive it differently. More complex operational characteristics make it clear that broadcast television operations are more complex and more involved. Because television is able to present a message in pictures and words that contain meaning, it can be said that television is able to make changes for audiences who watch.

Bungin (2006: 85-86) describes the main paradigm of mass media is as agent of change. In running paradigmanya this mass media play: (1) as an institution of enlightenment society, namely its role as educational media that at all times always educate the community; (2) as media of information, that is media which at any time deliver information to public; And (3) as an entertainment medium that also serves as a cultural institution. When acting as agent of change, as one of the mass media, television must provide enlightenment for the community with educational content. Television should be able to make people become more intelligent, open-minded and forward. For example, impressions that provide motivation, such as impressions Mario Teguh and Kick Andy. As an informer to the public, television is required to provide actual and reliable information. In this case, for example is a news program broadcast that is completely in accordance with the journalistic code of ethics. The role of television as an agent of change in displaying news programs can make people know a lot of the latest information going on around them. For example, news about the rampant crime that occurred in Jakarta, the news can make people become more alert and cautious. People can also be a more informative society. This is marked by the emergence of citizen journalism that aired on several television stations. As a medium of entertainment, television is also an institution that is able to encourage the development of culture that certainly useful and not harm the community. For example, impressions that cover about culture and natural wealth in Indonesia, such as Si Bolang or Indonesia Banget shows. The programming of $\mathrm{Si}$ Bolang and Indonesia Banget did not close the possibility will make people more love Indonesia's homeland and are interested to travel or enjoy the natural wealth in Indonesia. Television has the effect of social change for its audiences consuming television programs.

\section{II.II. The Role of Television as an Educative and Qualified Messenger}

The content of broadcasts in the mass media is regulated in Article 36 Paragraph 1 of Law No.32 of 2002 on Broadcasting. The article states that "broadcast content must contain information, education, entertainment, and benefits for the formation of intellect, character, morals, progress, nation power, maintaining unity and unity, and practicing Indonesian religious and cultural values". Based on what is contained in Law No.32 of 2002 on Broadcasting is clearly affirmed that every broadcast in any media must contain 
the content of quality and educational broadcast. Broadcasts capable of shaping the morale and intelligence of society. Television, as a medium to deliver a message to the audience must broadcast quality programs. A quality program is needed because the message is able to influence or persuade the audience who watch. Messages delivered by the television media can bring different responses and impacts to every audience.

When looking back on the broadcast that is on our television, there are still many who argue that our television media has not been able to meet all the aspects specified in broadcasting. The opinion expressed by the community was also supported by a survey of TV program quality indices conducted by the Indonesian Broadcasting Commission (KPI) in March-April 2015 (www.kpi.go.id). The survey gave results that the overall program index quality score was 3.25. KPI itself set the quality standard is 4.0 (qualified) with a scale of 1 to 5 . Event programs are called qualified if the score index score of at least 4.0. The overall program quality rating of the program shows that in general the quality of the television program is still below the quality standard of the KPI. The 3.25 index figure is the average of all television programs. The survey shows that the quality of television programs broadcast in Indonesia has not included quality program impressions.

Impressions broadcast by television should contain quality impressions considering the role of television that is able to change the behavior of its audience with the content of its broadcast. First of all the viewing impressions enter the mind, shaping or changing our perception of something, building an image of something and then changing our behavior. Asch (in Rachmat, 2009) concludes that neither attitude theory nor social action is based on an inquiry about its cognitive foundations. In short, attitude is determined by the image. Images are determined by information sources, such as mass media. Thus, the mass media does not change attitudes directly. Then the wisdom of the television media in broadcast the program. Through the positive messages and quality delivered by television, then it will bring positive changes also in shaping the behavior and character of the audience. Educational television shows have great power in educating people's lives. Television audiovisual impressions can make audiences easier to remember what they have seen and heard. This is what makes television need to understand their role as a messenger who must contain educational and quality content.

\section{II.III. Children as a Special Segmentation in} Television Media

The Indonesian Broadcasting Commission (KPI) drafted the Broadcasting Behavior and Broadcasting Program Standards (P3SPS) of 2012. In the Indonesian Broadcasting Commission Regulation No.01 / P / KPI / 03/2012 on Broadcasting Conduct Manual Article 21 explains that broadcast $\mathrm{P}$ is broadcasting for Children of pre-school age, ie, audiences with 2-6 years of age. While the broadcast classification A, is a broadcast for children who are 7-12 years old. The Regulation of the Broadcasting Commission of Indonesia No.01 / P / KPI / 03/2012 on the Guidelines for Behavior of Broadcasting also regulates the protection of children as set forth in Chapter X Article 14, ie broadcasters shall provide protection and empowerment to children by broadcasting broadcast programs at a time Exactly in 
accordance with the broadcast program classification and also must pay attention to the interests of the child in every aspect of broadcast production. Included in the broadcasting institutions are television. It is clear that television is compulsory to pay attention to the child's interests and provide broadcasts with quality content and appropriate delivery times for children.

Children are a special segmentation that is worth noting in the world of broadcasting, especially television. Television as an audiovisual medium is very capable to influence its audiences. Children are still vulnerable to influence, They have not been able to think deeper about the impact of television impressions. This is because they can not distinguish between what is fictitious and what is real. Children also have not been able to understand which shows are not good to watch, which are inconsistent with ethics, morals, cultural and religious values, or norms. This is what causes the television media can easily embed his messages in children without being processed or studied first by the children.

Dr. Aric Sigman (in health.detik.com) disclosed children under the age of 3 should have little or no time to watch television every day, 3-7-year-olds should be allowed to watch television for no more than 90 minutes and adolescents Up to 18 years may only be a maximum of 2 hours per day. The more children watch television, the more the negative effects or effects they may have. The more children watch television, the more difficult it is to distinguish real life and fiction. Finally because they absorb a lot of things from television, they will bring what they watch into the real world.

Why should children be considered as a special segmentation in television shows? Various television shows contain elements of violence, fights, swearing, insults, and so forth. Children, in this case not only watch special programs children. Not a few of those who also consume impressions-programs outside the child's program and this is not good impact. There can be casualties from consuming impressions that contain dangerous and non-educational content. For example, at the end of April 2015, there was an elementary school boy in Pekanbaru who died of a raid by his friends. According to the victim's parents' information, the victim and his friends were playing to imitate the fight scene in the 7 tiger human soap operas that aired on RCTI. His friends hit with a broom and kicked as depicted in the soap opera. As a result of this incident, the victim suffered nerve damage and died after being treated at the hospital (www.remotivi.or.id). There was also the incident of the death of a 5-yearold boy who jumped from the 15th floor of an apartment building in North Jakarta. The boy is rumored to jump as inspired by Spiderman (www.news.liputan6. com). These two cases are just one of the many cases of non-educational television shows. Program impressions are not intended for children. Given that children are very happy to imitate what they see, then the role of parents and family is necessary. The role of the television as a media broadcaster is also required where it should display quality impressions in accordance with applicable standards and rules.

On television shows, such as Tom \& Jerry, it is worth noting further deepening of the impression. Tom \& Jerry cartoons are a kind of cartoon based slapstick comedy or rough comedy. The cartoon shows if watched by children does not rule out the possibility of violent acts committed by children who imitate scenes in cartoons. 
The other impressions are Crayon Shinchan impressions. Crayon Shinchan is a manga series of black comedy, sliceof-life, and slapstick. Even on his own comic, Crayon Shinchan is for adults, not for children. Therefore, it is better for the television party to deepen the first impressions that will be broadcast for the children. Children need special attention in this regard.

Children need to be noticed because they are figures who simply learn and imitate what they see. Television in this case becomes a tool in "helping" children to learn something new. Related to the learning and imitation of children in watching television, we can see experiments ever performed by Bandura (1961), the experiment Bobo Doll Behavior: A Study of Aggression. In this experiment, Bandura showed a film to children containing violent and aggressive content. Then Bandura puts the children in a room with a Bobo doll. The experimental results suggest that children who watch violent films tend to commit violent and aggressive acts against the doll. Bandura's experiments support the assertion that children can learn a lot from television and imitate what they see but they can not yet understand which messages are good or bad based on the ethics and norms that are practiced in society.

\section{METHODOLOGY}

\section{Ethics in Child Program Impressions} on Television

We must talk about ethics if we talk about morality. Plaisance (2014: 8-9) explains that ethics and morality are closely related. Morality in general is the composition or set of beliefs we know to help us understand what is good and what is bad in the world. Usually we do not question the truth of this belief. While ethics relates to our struggle in giving reasons for doing or not doing something when some of the values of our belief systems are in conflict. More specifically, morality focuses on the quality of goodness, the ethics of focusing on the truth on the actions it takes.

Associated with ethics, television shows must follow the rules. Law No.32 of 2002 on Broadcasting affirms that the content of the broadcast is prohibited slanderous, inciting, misleading and / or untrue; Highlight elements of violence, obscenity, gambling, abuse of narcotics and drugs; Or to contrast ethnic, religious, racial, and intergroup. The content of the broadcast is also prohibited to stigmatize, demean, harass and / or ignore the values of religion, the dignity of Indonesian human beings, or damage international relations. However, there are still television stations that often broadcast programs with content that contain elements of violence. Not just impressions for adults, impressions that are 'stamped' as children's impressions also have elements of violence. According to Rakhmat (2009: 243), film (television) often presents scenes of murder, rape, vandalism, and so on, which damage or harm others. This violent scene is often considered a "bustling" part of the movie presentation. The audience likes it and the producers also of course love it. Television shows, both impressions for adults, children, and even all ages are mostly pursuing a 'profit'. The more that fond of the show, the more income for the television media.

It is unfortunate that this time the quality of children's programs on television is diminishing. For example, children's programming shows on SCTV, Elif Indonesia and La Academia Junior Indonesia. These two programs became the children's program that always aired. 
Can be seen for the La Academia Junior Indonesia show aired every Sunday at 14.00, although this event is a talent show for children, but the songs that are often sung by the children are adult songs that may even own children Not understanding the meaning or intent of the song. Similarly, Elif Indonesia's impressions are considered to imitate the impressions of Elif from Turkey. Impressions broadcasted everyday at 15.00 hours are segmented for children. However, the show is inseparable from some violent scenes by Elip's adoptive father to Elif and his mother. Then where are the other child program impressions? Impressions of child programs on RCTI are slightly different. RCTI is still singing some special broadcasts of children in the form of animations, such as New Kiko and Wonderful World of Disney.

Looking back at the results of the TV quality program quality index survey conducted by KPI, the results also show that for the children's program, the respondents rated the quality of children's event programs as lacking quality. KPI set the quality standard is 4.0 (qualified) with a scale of 1 to 5 . Event programs can be called qualified if the index score a minimum of 4.0. While in this survey, the quality index obtained for the children's program is 3.03 and this index is still below the 4.0 (qualified) number established by KPI. Television programs for children are still not considered qualified and worth watching for by children.

Indonesian Broadcasting Commission Regulation No.02 / P / KPI / 03/2012 on Broadcast Program Standards Article 36 Paragraphs 1, 2, 3 and 4 outline affirmed the standards on child program broadcasts in which child program impressions are specifically created and intended for children. (Both verbal and nonverbal), should not contain content that teaches children to do things that are inappropriate, does not contain horrific and frightening scenes, and must contain elements related to the child's development. The values of education, manners, good entertainment, and others. According to Burton (2007), children as television audiences are always seen as special cases, because children are assumed to be easily suggestive and vulnerable to influence. Children thrive in different ways at different ages. Children grow in different environments, which may or may not help children interpret the television. This is why television media should pay attention to the content of the content of children programs. The tendency of children in filtering the contents of the message a special attention.

Pramadiansyah (2014), in his paper entitled "The Influence of Television in the Establishment of Violent Behavior" states that the most fundamental problem in Indonesia is the tendency of Indonesian children to filter out television shows. Referring to Gerbner's opinion in Cultivation theory, we know everything through the stories we see and hear in the media without us knowing what really happened. Children seem to think that the show is something that really happened and witnessed by many people. Imitative or imitative behavior is very prominent in children. The more views that contain the element of violence on television, the more vulnerable children who have the habit of watching television to imitate these habits in everyday life.

tTelevision impressions, especially for children, are sometimes associated with violence. The media should be aware of the vulnerability of children in consuming such impressions. Huesman and Eron (in Burton, 2007) explain that various interpretations of research that lead to 
the effects of television on children, sometimes appear to fall into the category of "moral panic." The media cited several reports and temporarily created anxiety climate. Factors such as the tendency for more aggressive children to watch more television that shows violence tend to be ignored. In addition to special program impressions of children, other impressions that can be consumed by children should also keep in mind the elements that do not educate. Parents take part in explaining or guiding the child while watching the show together.

Impressions of children's programs on television are closely related to display ethics, such as child-friendly content, scheduling shows, playback of ads in child programs, and so on. Children's program impressions containing childspecific content and are considered educational, such as Unyil, Si Komo, Family Fir, Sherina Adventure, and others have disappeared from the world of television. The children of old, as in the 90s still know child songs, such as regional songs, rainbows, balloons There are Five, or children's special songs sung by little artists. Even in the 1990s, private television was still broadcasting children's programs that broadcast children's songs, such as Tralala Trilili (Agnes Monica) or Klip Klip (Dhea Ananda). The loss of quality and quality children's impressions is unfortunate given that children also need to learn about things around the world on television. Children need impressions that help them to develop their knowledge and personality with good morals and values.

In addition to paying attention to the content, the program impressions of children on television also need to pay attention to the schedule penanyangannya. The child's programming schedule at that time follows the child's schedule in learning, playing and resting. Indonesian Broadcasting Commission Regulation No.02 / P / KPI / 03/2012 on Broadcast Program Standards Article 36 Clause 5 stipulates that the child's special broadcast time is 5:00 to 18:00 o'clock. But nowadays, some children's programs are aired outside the designated time. Views beyond the specified time can certainly interfere with the schedule of children to do other than relax and watch television, such as learning activities, napping, playing, or gathering with family. Good children's impressions with an appropriate schedule also help the child in dividing time and learning discipline. As time passes, they will understand that the impressions that are broadcast outside of watch time are not impressions intended for themselves.

\section{RESULTS AND DIS- CUSSION}

The mass media has such a big role for society. Television as a mass media must undergo its role as a medium that provides information, educate, entertain and also as a supervisor and social adhesive. The function of television not only pay attention to profit or rating alone, but also how the television is able to make the audience into a smart society, open minded, advanced and qualified. Television as an audiovisual medium has great power in making audiences remember what they see and hear. Because of this power then the television as an information medium is necessary to provide educational information.

Children as the next generation of the nation must be considered as one segmentation of television audiences. They should get special attention by the television media in broadcasting its 
impressions. Children have not been able to distinguish which is the fictitious thing which is real. They are very easy to imitate what they see. Children learn from the things they see and hear. Television as an audiovisual medium is able to provide many things that children can learn.

Television as the information giver is obliged to provide educational messages through its programs. The programs broadcast on television are still not qualified, especially children's programs. Television should present a child program of impressions appropriate to the child's development. Ethics are important in educating children. When television broadcasts educational and quality shows, good morals and educational values are formed within the child from an early age.

\section{REFERENCES}

Book and Journals :

Ardianto, Elvinaro., Lukiati Komala, dan Siti Karlinah. 2004. Komunikasi Massa: Suatu Pengantar. Edisi Revisi. Simbiosa Rekatama Media. Bandung.

Bandura, Albert. 1965. Influence of Models Reinforcement Contingencies on The Acquisition of Imitative Responses. Journal of Personality and Social Psychology 1: 589-595.
Bungin, Burhan. 2006. Sosiologi Komunikasi: Teori, Paradigma, dan Diskursus Teknologi Komunikasi di Masyarakat. Edisi Pertama. Cetakan Kelima. Kencana. Jakarta.

Burton, Graeme. 2000. Talking Television: An Introduction to the Study of Television. Hodder Education Publishers. London. Terjemahan Laily Rahmawati. 2007. Memperbincangkan Televisi: Sebuah Pengantar Kepada Studi

Televisi. Jalasurta. Yogyakarta.

Croteau, David., William Hoynes dan Stefania Milan. 2012. Media Society: Industries, Images, and Audiences. Fourth Edition. SAGE. USA.

Rakhmat, Jalaluddin. 2009. Psikologi Komunikasi. Cetakan Keduapuluh tujuh. PT. Remaja Rosdakarya. Bandung.

Plaisance, Patrick Lee. 2014. Media Ethics: Key Principles for Responsible Practice. Second Edition. SAGE. USA.

Pramadiansyah, Yudhi. 2014. Pengaruh Televisi dalam Pembentukan Perilaku Kekerasan. Makalah Non-Seminar. Ilmu Komunikasi Fakultas Ilmu Sosial dan Ilmu Politik Universitas Indonesia. Depok. 